\title{
Fabrication and Characterization of PCBM: P3HT-based Thin-film Organic Solar Cells with Zinc Phthalocyanine and 1,8-Diiodooctane
}

\author{
Haruto Maruhashi ${ }^{1}$, Takeo Oku ${ }^{1, *}$, Atsushi Suzuki ${ }^{1}$, Tsuyoshi Akiyama ${ }^{1}$, Yasuhiro Yamasaki ${ }^{2}$ \\ ${ }^{1}$ Department of Materials Science, the University of Shiga Prefecture, Japan \\ ${ }^{2}$ Department of New Business, Orient Chemical Industries Co. Ltd., Japan
}

Copyright $\bigcirc 2017$ by authors, all rights reserved. Authors agree that this article remains permanently open access under the terms of the Creative Commons Attribution License 4.0 International License

\begin{abstract}
C}_{61}$-butyric acid methyl ester (PCBM) and poly(3-hexylthiophene) (P3HT) bulk heterojunction solar cells added with zinc-tetra-tertiary-butyl-phthalocyanine ( $\mathrm{ZnPc})$ and 1,8-diiodooctane (DIO) were fabricated and characterized. Incident photon-to-current conversion efficiencies in the range of 400-650 $\mathrm{nm}$ were increased by the $\mathrm{ZnPc}$ addition, and the absorption range of $\mathrm{ZnPc}$ overlapped with the photoluminescence range of P3HT. Photovoltaic properties of the solar cells with an inverted structure were improved by the $\mathrm{ZnPc}$ and $\mathrm{DIO}$ addition. Microstructures of the thin films were analyzed by X-ray diffraction. The improvement would be due to the Förster energy transfer mechanism the direct charge transfer from $\mathrm{ZnPc}$ to PCBM, and the phase separation of PCBM and P3HT by the DIO addition would also contribute the improvement.
\end{abstract}

Keywords Thin Film, Phthalocyanine, Solar Cell

\section{Introduction}

Organic thin-film solar cells have been developed as next-generation solar cell systems, and they have advantages of low cost, flexibility and light weight [1-3]. They can be fabricated at low temperatures by spin-coating and printing methods $[4,5]$. Polymer solar cells using poly(3-hexylthiophene) (P3HT) and [6,6]-phenyl $\mathrm{C}_{61}$-butyric acid methyl ester (PCBM) have been widely investigated, and the conversion efficiency of $\sim 5 \%$ was obtained [6,7]. Organic solar cells consisting of P3HT and PCBM exhibited good incident photon-to-current conversion efficiency (IPCE) and fill factor (FF). The device performance of such polymer solar cells can be affected by the preparation condition such as annealing temperatures, concentration of starting materials and film thicknesses [8-10].

Addition of the third components such as phthalocyanines, naphthalocyanines and low-band-gap polymers is expected to absorb light that the P3HT and PCBM cannot collect. Since phthalocyanines absorb near-infrared light, effects of addition of silicon phthalocyanine, silicon naphthalocyanine or germanium phthalocyanine to the P3HT: PCBM system were investigated [11-17]. Solubilized metal phthalocyanines (MPc) could be dissolved in organic solvents, and the application for the device process using a spin-coating method could be expected.

MPc are groups of small molecular materials with Q-band absorption in the near-infrared ranges. Since they have high chemical stabilities and photovoltaic property, they can be used as donor materials for the organic solar cells. Heterojunction solar cells consisting of copper phthalocyanine and fullerene were fabricated by an evaporation method and their power conversion efficiencies was $\sim 3 \%$ [18]. Characteristics such as absorption, conversion efficiencies and microstructures of thin film solar cells were investigated by changing the central metals of MPc [19-21].

The purpose of this work is to fabricate and characterize bulk heterojunction solar cells with an inverted structure using P3HT, PCBM and zinc-tetra-tertiary-butyl phthalocyanine $(\mathrm{ZnPc})$. The $\mathrm{ZnPc}$ was added as the third component for PCBM: P3HT solar cells. 1,8-diiodooctane (DIO) was also added to improve the photovoltaic properties $[22,23]$. The polarity of charge collection is reversed from conventional devices in the inverted structure [24-26], which are expected to provide stable devices in air [27-30]. The photovoltaic mechanism and an energy level diagram of the present solar cells were discussed on the basis of light-induced current density-voltage $(J-V)$ curves and IPCE. The microstructures of thin films were investigated by $\mathrm{X}$-ray diffraction (XRD). 


\section{Experimental Procedures}

\subsection{Materials}

The molecular structures of organic semiconductor materials such as P3HT (Merck), ZnPc (Orient Chemical Industries), PCBM (American Dye Source), and DIO were used, as shown in Fig. 1(a), (b), (c) and (d), respectively. The $\mathrm{TiO}_{\mathrm{x}}$ precursor solution was prepared from titanium isopropoxide (TTIP), and Indium tin oxide (ITO, Xin Yan Technology, $\sim 10 \Omega / \square$ ) was also used for substrates of the present photovoltaic devices.

\subsection{Device Fabrication}

Solar cells with an inverted structure were fabricated by the following process. ITO substrates were cleaned by an ultrasonic bath with acetone and methanol and dried with nitrogen gas. The $\mathrm{TiO}_{\mathrm{x}}$ precursor solution was prepared from TTIP, 2-methoxyethanol, and acetylacetone. TTIP $(0.5 \mathrm{~mL})$ was added to $2-$ methoxyethanol $(2.5 \mathrm{~mL})$ and acetylacetone $(0.422 \mathrm{~mL})$ [15]. The $\mathrm{TiO}_{\mathrm{x}}$ precursor solution was spin-coated on the ITO substrate at $2000 \mathrm{rpm}$. After annealing at $150{ }^{\circ} \mathrm{C}$ for $60 \mathrm{~min}$ in air, an organic layer was prepared on the $\mathrm{TiO}_{\mathrm{x}}$ layer by spin coating at $1000 \mathrm{rpm}$ using a mixed solution of P3HT (15 mg), PCBM (10 mg), and $\mathrm{ZnPc}$ in $o$-dichlorobenzene $(1 \mathrm{~mL})$. A weight ratio of $\mathrm{ZnPc}$ in PCBM:P3HT:ZnPc powders was changed 1, 3 and $5 \%$. 1,8-diiodooctane was added 3 vol\% in mixed solution of P3HT, PCBM and ZnPc. After annealing at $140{ }^{\circ} \mathrm{C}$ for 5 min in air, a PEDOT:PSS layer was spin-coated on the organic layer at $2000 \mathrm{rpm}$, and annealed at $100{ }^{\circ} \mathrm{C}$ for $5 \mathrm{~min}$ in air. Finally, gold $(\mathrm{Au})$ metal contacts were evaporated as top electrodes. A solar cell without $\mathrm{ZnPc}$ was denoted as PCBM:P3HT. PCBM:P3HT solar cells added with $0 \mathrm{wt} \%$, $1 \mathrm{wt} \%, 3 \mathrm{wt} \%$ and $5 \mathrm{wt} \% \mathrm{ZnPc}$ were denoted as PCBM:P3HT, PCBM:P3HT(ZnPc1), PCBM:P3HT(ZnPc3) and PCBM:P3HT(ZnPc5), respectively. PCBM:P3HT solar cells added with $0 \mathrm{wt} \%, 1 \mathrm{wt} \%, 3 \mathrm{wt} \%$ and $5 \mathrm{wt} \% \mathrm{ZnPc}$ and 3 vol\% DIO were denoted as PCBM:P3HT-D, PCBM:P3HT(ZnPc1-D), PCBM:P3HT(ZnPc3-D) and PCBM:P3HT(ZnPc5-D), respectively. Layered structures of bulk heterojunction solar cells with the inverted structure were shown schematically in Fig. 2.

\subsection{Characterization}

The $J-V$ characteristics (Hokuto Denko HSV-110) of the solar cells were measured both in the dark and under

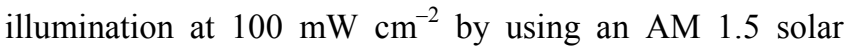
simulator (San-ei Electric XES-301S). The solar cells were illuminated through the side of the ITO substrates, and the illuminated area was $0.16 \mathrm{~cm}^{2}$. External quantum efficiencies (EQE) were also measured (Enli Technology, QE-R). Optical absorption of the solar cells was investigated by ultraviolet-vis-near-infrared spectrophotometer (Jasco, V-670ST). Photoluminescence
(PL) was investigated by spectrofluorometer (Jasco, FP-6600). Microstructures of the thin films were investigated by XRD analysis (Bruker, D2 Phaser) with $\mathrm{Cu}$ $\mathrm{K} \alpha$ radiation. Crystallite sizes were calculated by Scherrer's equation. (a)

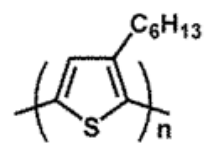

(c)

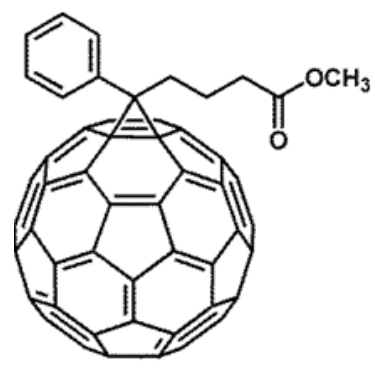

b)

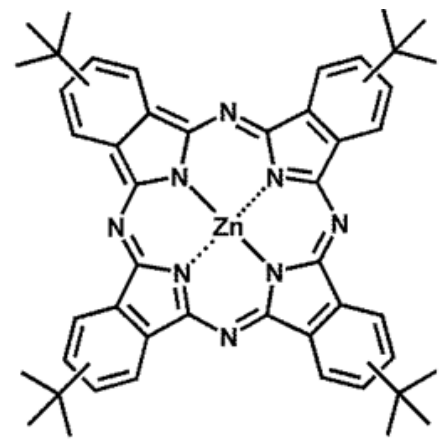

(d)

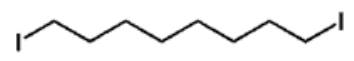

Figure 1. Structures of (a) P3HT, (b) ZnPc, (c) PCBM, and (d) DIO.

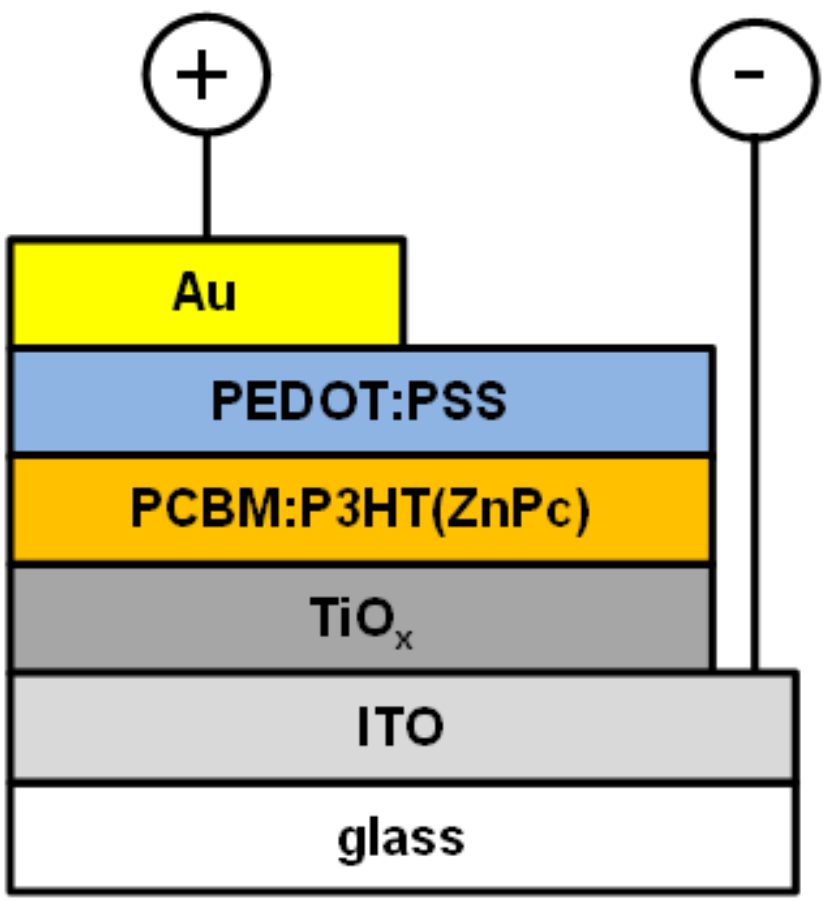

Figure 2. Schematic illustration of solar cell devices.

\section{Results and Discussion}

Figure 3 shows absorption spectra of PCBM:P3HT, PCBM:P3HT(ZnPc1), PCBM:P3HT(ZnPc3) and PCBM:P3HT(ZnPc5) and $\mathrm{ZnPc}$ thin films and a photoluminescence spectrum of a P3HT thin film. The absorption measurement region is in the range of 300-800 nm. $\Delta$ absorbance indicates the subtracted absorbance of 
ITO/ $\mathrm{TiO}_{\mathrm{x}}$. The optical absorption at $350 \mathrm{~nm}$ corresponds to the Soret band of $\mathrm{ZnPc}$. The optical absorption in the range of 400-650 nm corresponded to P3HT, and absorption at $\sim 400 \mathrm{~nm}$ was attributable to PCBM. The optical absorption in the range of 550-750 nm corresponds to the Q-band of $\mathrm{ZnPc}$. The optical absorption range of PCBM:P3HT(ZnPc) film was expanded in the range of $400-750 \mathrm{~nm}$ by the $\mathrm{ZnPc}$ addition. The light with a wavelength of $460 \mathrm{~nm}$ was used for excitation of the P3HT, and a photoluminescence peak is observed at $\sim 650 \mathrm{~nm}$. The absorption range of $\mathrm{ZnPc}$ overlapped with the photoluminescence range of $\mathrm{P} 3 \mathrm{HT}$ around $650 \mathrm{~nm}$.

Measured parameters of PCBM:P3HT(ZnPc) solar cells are summarized in Table 1. Short-circuit current density, open-circuit voltage, fill factor and power conversion efficiency are denoted as $J_{S C}, V_{O C}, F F$ and $\eta$, respectively. Figure 4 shows measured $J-V$ characteristic curves of the PCBM:P3HT( $\mathrm{ZnPc})$ solar cells, and the $J_{S C}$ was improved by the $\mathrm{ZnPc}$ addition. The PCBM:P3HT(ZnPc3) solar cell provided $J_{S C}$ of $3.73 \mathrm{~mA} \mathrm{~cm}$ ch $^{-2}$ and $0.653 \%$, which were better than those of other PCBM:P3HT(ZnPc) devices in this work. The EQE spectra of solar cells are shown in Fig. 5. The EQE peaks were improved at $\sim 730 \mathrm{~nm}$ for the solar cell with $\mathrm{ZnPc}$, which is due to the optical absorption of the $\mathrm{ZnPc}$. In addition, EQE were enhanced in the range of $300-650 \mathrm{~nm}$. The enhancement would be stemmed from energy transfer mechanism by the ZnPc.

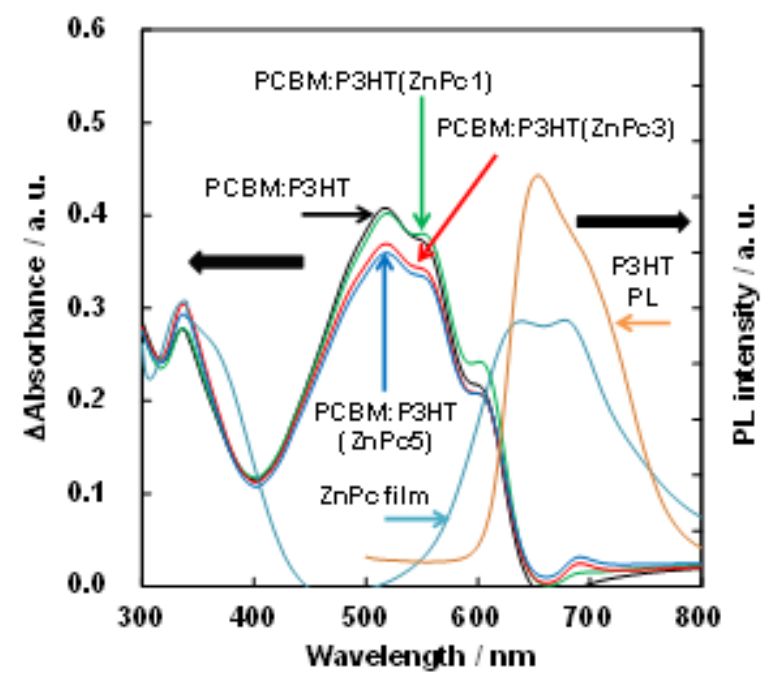

Figure 3. Optical absorption spectra of PCBM:P3HT( $\mathrm{ZnPc}), \mathrm{ZnPc}$ thin films, and photoluminescence spectrum of P3HT thin film.

Table 1. Measured parameters of PCBM:P3HT( $\mathrm{ZnPc})$ solar cells.

\begin{tabular}{ccccc}
\hline $\mathrm{ZnPc}(\mathrm{wt} \%)$ & $J_{S C}\left(\mathrm{~mA} \mathrm{~cm}^{-2}\right)$ & $V_{O C}(\mathrm{~V})$ & $F F$ & $\eta(\%)$ \\
\hline 0 & 3.41 & 0.452 & 0.403 & 0.621 \\
1 & 3.56 & 0.424 & 0.408 & 0.615 \\
3 & 3.73 & 0.435 & 0.403 & 0.653 \\
5 & 3.56 & 0.422 & 0.398 & 0.597 \\
\hline
\end{tabular}

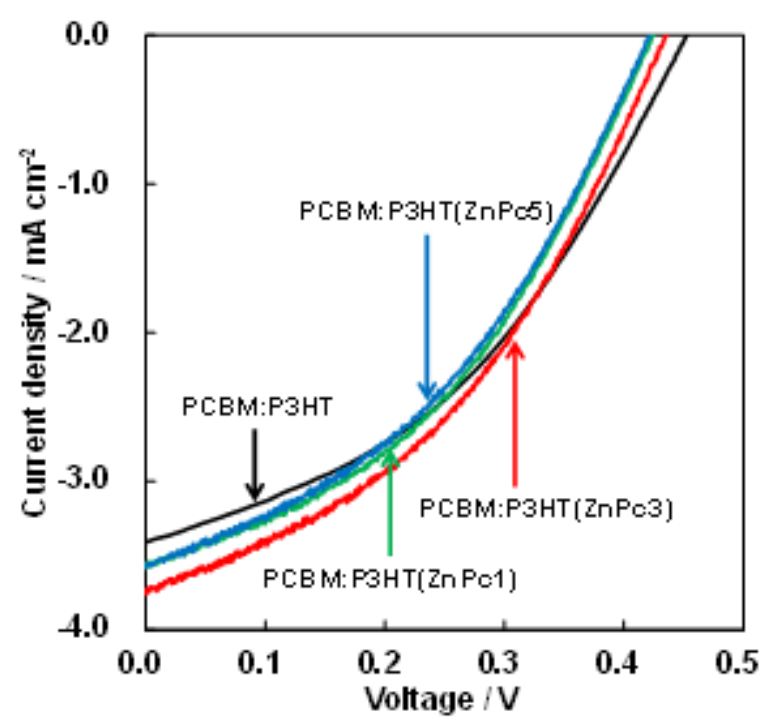

Figure 4. $J-V$ characteristics of $\mathrm{PCBM}: \mathrm{P} 3 \mathrm{HT}(\mathrm{ZnPc})$ solar cells.

Figure 6 shows absorption spectra of PCBM:P3HT(ZnPc) solar cells with DIO. Measurement region of the absorption is in the range of $300-800 \mathrm{~nm}$. The optical absorption of P3HT in the range of 400-650 nm was slightly improved by the DIO addition. Absorption around $700 \mathrm{~nm}$ increased by the $\mathrm{ZnPc}$ addition compared with the PCBM:P3HT-D.

Measured parameters of the PCBM:P3HT( $\mathrm{ZnPc})$ solar cells with DIO are summarized in Table 2. Figure 7 shows measured $J-V$ characteristic curves of PCBM:P3HT(ZnPc-D) solar cells. The $J_{S C}$ of PCBM:P3HT with DIO was $4.67 \mathrm{~mA} \mathrm{~cm}$, which is higher than that of $3.41 \mathrm{~mA} \mathrm{~cm}$-2 for PCBM:P3HT cells. This indicates that the $J_{S C}$ was improved by the DIO addition. However, $J_{S C}$ of solar cells added with $\mathrm{ZnPc}$ and $\mathrm{DIO}$ were a little lower than that of solar cell without $\mathrm{ZnPc}$. The $\mathrm{ZnPc}$ might prevent the phase separation by DIO addition.

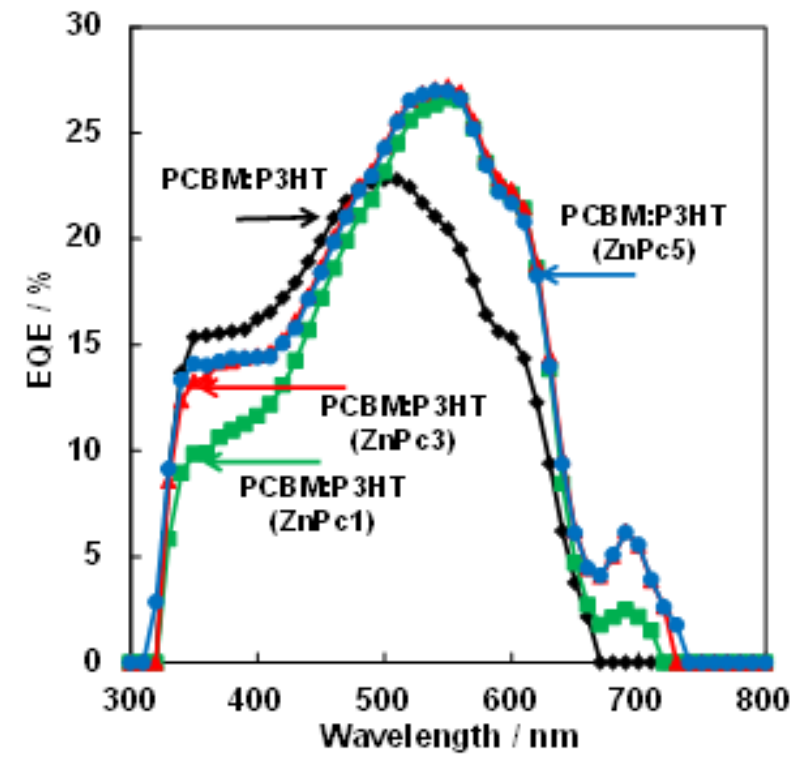

Figure 5. EQE spectra of PCBM:P3HT(ZnPc) solar cells. 


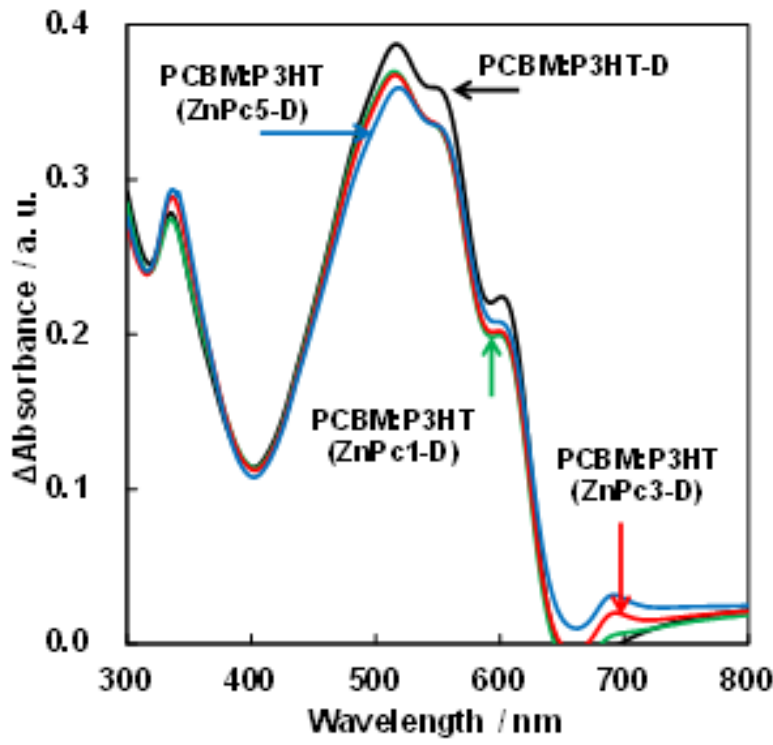

Figure 6. Optical absorption spectra of thin films of PCBM:P3HT(ZnPc) with DIO.

The EQE spectra of PCBM:P3HT(ZnPc-D) solar cells are shown in Fig. 8. The EQEs of all solar cells were improved by the DIO addition. Especially, PCBM:P3HT-D solar cell provided high EQE in the range of $450-650 \mathrm{~nm}$. On the other hand, EQEs are observed at $700 \mathrm{~nm}$ by the $\mathrm{ZnPc}$ addition, and the values increased as the amount of $\mathrm{ZnPc}$ increased.

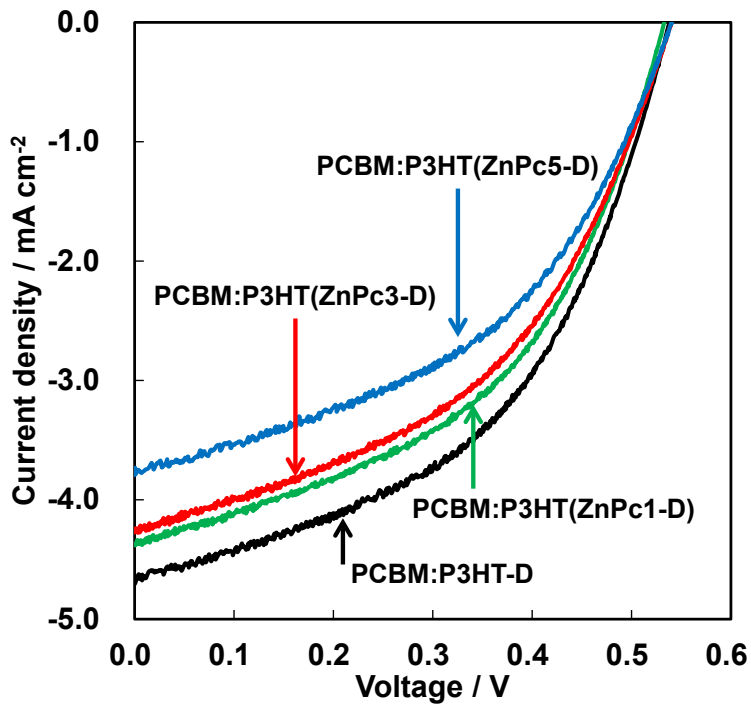

Figure 7. $J-V$ characteristics of PCBM:P3HT(ZnPc) with DIO.

Table 2. Measured parameters of PCBM:P3HT(ZnPc) solar cells with DIO.

\begin{tabular}{ccccc}
\hline $\mathrm{ZnPc}(\mathrm{wt} \%)$ & $J_{S C}\left(\mathrm{~mA} \mathrm{~cm}^{-2}\right)$ & $V_{O C}(\mathrm{~V})$ & $F F$ & $\eta(\%)$ \\
\hline 0 & 4.67 & 0.539 & 0.483 & 1.21 \\
1 & 4.37 & 0.533 & 0.475 & 1.11 \\
3 & 4.27 & 0.539 & 0.458 & 1.06 \\
5 & 3.79 & 0.540 & 0.458 & 0.936 \\
\hline
\end{tabular}

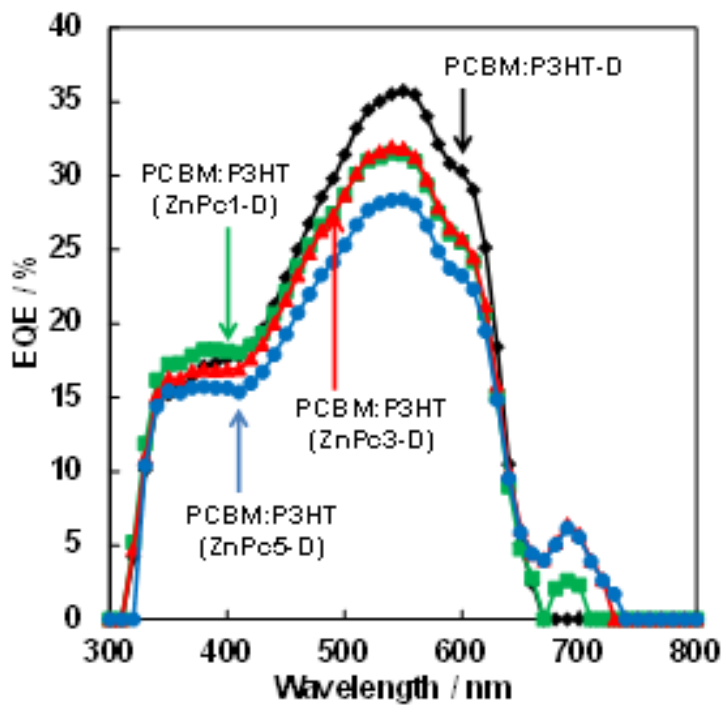

Figure 8. EQE spectra of PCBM:P3HT(ZnPc) with DIO.

XRD patterns of PCBM:P3HT, PCBM:P3HT( $\mathrm{ZnPc})$, PCBM:P3HT-D and PCBM:P3HT(ZnPc-D) thin films are shown in Figure 9. Lattice parameters and crystallite sizes of PCBM:P3HT, PCBM:P3HT(ZnPc), PCBM:P3HT-D and PCBM:P3HT(ZnPc-D) thin films are summarized in Table 3. Diffraction peaks were observed for P3HT, PCBM:P3HT, PCBM:P3HT(ZnPc), PCBM:P3HT-D and PCBM:P3HT(Z $\mathrm{nPc}-\mathrm{D}$ ), which indicated that the P3HT have crystalline structures with lattice distances of 16.83, 16.41, 16.58, 16.55 , and $16.58 \AA$, respectively. On the other hands, no sharp diffraction peak is observed for $\mathrm{ZnPc}$ and PCBM, which indicates that the $\mathrm{ZnPc}$ and $\mathrm{PCBM}$ has an amorphous structure. P3HT nanowires would be dispersed in the PCBM amorphous matrix, which had already been confirmed by XRD and transmission electron microscopy analyses in the previous work [15].

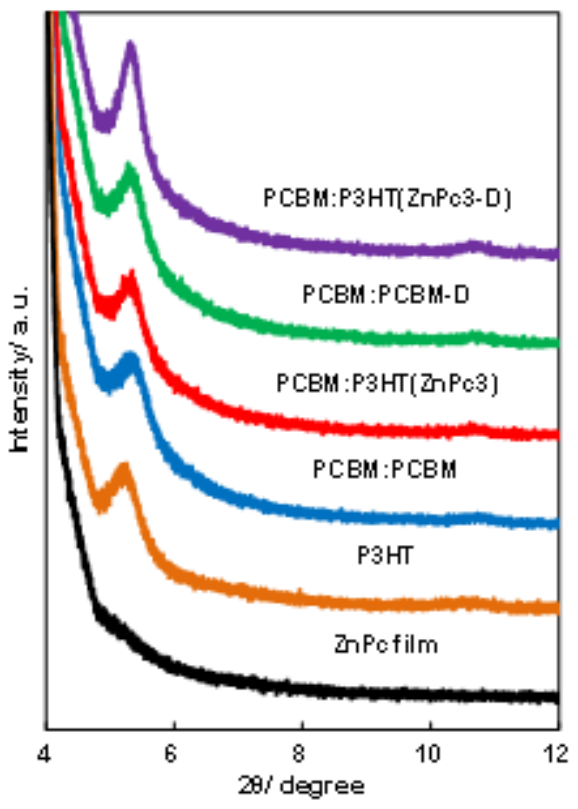

Figure 9. XRD patterns of thin films of $\mathrm{ZnPc}$, P3HT, PCBM:P3HT, PCBM:P3HT(ZnPc), PCBM:P3HT-D, and PCBM:P3HT(ZnPc)-D. 
Table 3. XRD results of the present thin films.

\begin{tabular}{cccc}
\hline Sample & $\begin{array}{c}2 \theta \\
\left({ }^{\circ}\right)\end{array}$ & $\begin{array}{c}d \text {-spacing } \\
(\AA)\end{array}$ & $\begin{array}{c}\text { Crystallite } \\
\text { size }(\AA)\end{array}$ \\
\hline P3HT & 5.247 & 16.83 & 219 \\
P3HT:PCBM & 5.381 & 16.41 & 220 \\
P3HT:PCBM(ZnPc) & 5.327 & 16.58 & 244 \\
P3HT:PCBM-D & 5.335 & 16.55 & 290 \\
P3HT:PCBM(ZnPc-D) & 5.326 & 16.58 & 263 \\
\hline
\end{tabular}
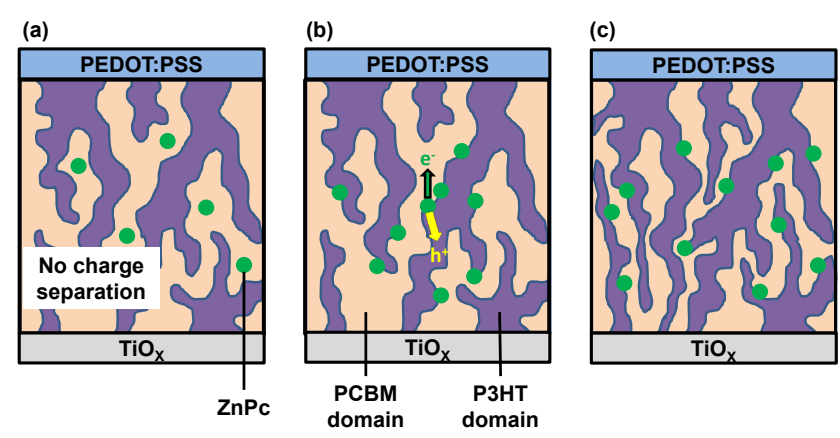

Figure 10. Schematic illustration of dispersion states of $\mathrm{ZnPc}$ (a) in PCBM matrix, (b) at the PCBM/P3HT interface and (c) with DIO.

(a)

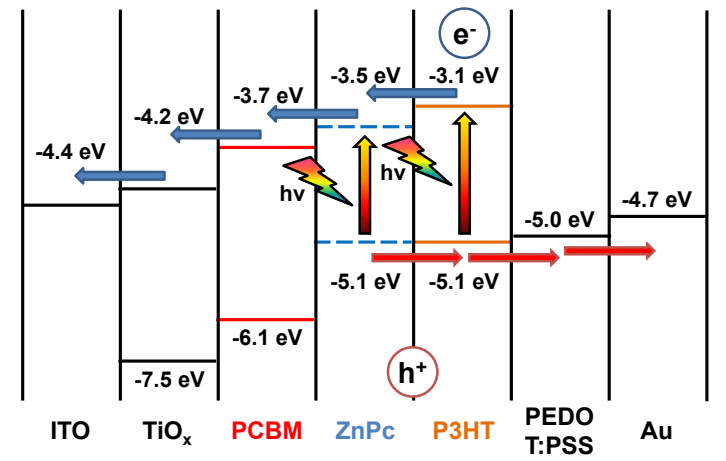

(b)

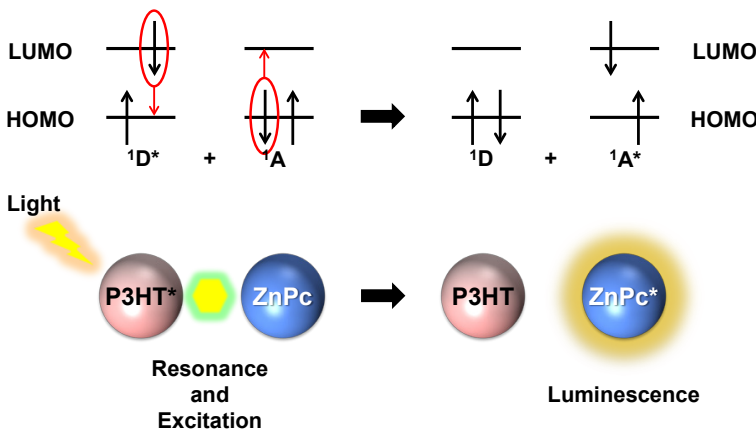

Figure 11. (a) Energy level diagram of PCBM:P3HT(ZnPc) solar cell. (b) Schematic illustration of Förster energy transfer mechanism.

Crystallite sizes of P3HT, PCBM:P3HT, PCBM:P3HT(Z nPc), PCBM:P3HT-D and PCBM:P3HT(ZnPc-D) were calculated to be $219,220,244,290$ and $263 \AA$, respectively. The addition $\mathrm{ZnPc}$ and DIO facilitated the increase of the lattice parameters of $\mathrm{P} 3 \mathrm{HT}$ crystalline. The crystallite size of PCBM:P3HT-D was the largest, and the solvent additive would facilitate the crystal growth and phase separation of PCBM:P3HT layers.
Interfacial structure models and an energy level diagram of the present PCBM:P3HT( $\mathrm{ZnPc})$ solar cell are summarized and illustrated, as shown in Figures 10 and 11, referring the previous models and mechanisms [3,15-19]. If the $\mathrm{ZnPc}$ molecules exist in the PCBM domain, charge transfer does not occur, as shown in Fig. 10(a). Therefore, the $\mathrm{EQE}$ peaks of $\mathrm{ZnPc}$ would appear only when the $\mathrm{ZnPc}$ molecules exist at the PCBM:P3HT interface. When the $\mathrm{ZnPc}$ molecules exist at the $\mathrm{PCBM} / \mathrm{P} 3 \mathrm{HT}$ interface as illustrated in Fig. 10(b), photo-excitation would occur at the $\mathrm{PCBM} / \mathrm{ZnPc}$ interface. When the DIO was added, the crystallite sizes of P3HT increased, which indicates the growth of the P3HT perpendicular to the substrate, as illustrated in Fig. 10(c). Then, the interfacial area increase, which resulted in the $J_{S C}$ values.

For the cell with the inverted structure, electrons are transported to an ITO substrate, and holes are transported to an $\mathrm{Au}$ electrode, as illustrated in Fig. 11(a). Light irradiation promoted to generate charge separations. The excited electrons in the conduction band of the P3HT would slightly diffuse and transfer from $\mathrm{P} 3 \mathrm{HT}$ to Au electrode. The holes in the valence band of the P3HT would pass through PEDOT:PSS layer to the ITO substrate. The energy levels of the conduction band or lowest unoccupied molecular orbital (LUMO) for $\mathrm{P} 3 \mathrm{HT}, \mathrm{ZnPc}$ and $\mathrm{PCBM}$ are $-3.1 \mathrm{eV},-3.5 \mathrm{eV}$ and $-3.7 \mathrm{eV}$, respectively. Since the LUMO value of the $\mathrm{ZnPc}$ is between those of P3HT and PCBM, electrons could transport from P3HT to PCBM [16].

The EQE values in the range of 300-650 $\mathrm{nm}$ were increased by the $\mathrm{ZnPc}$ addition, which could be explained by the Förster energy transfer from the $\mathrm{P} 3 \mathrm{HT}$ to $\mathrm{ZnPc}$. Figure 11(b) shows Förster energy transfer mechanism, which occurs when the photoluminescence spectrum of a donor material and the photo-absorption spectrum of an acceptor material are overlapping [31,32]. In the present work, the donor and acceptor materials are $\mathrm{P} 3 \mathrm{HT}$ and $\mathrm{ZnPc}$, respectively. As shown in Fig. 3, the optical absorption spectra of $\mathrm{ZnPc}$ thin film and the photoluminescence spectrum of P3HT thin film are overlapping. Then, the Förster energy transfer would occur between the P3HT and ZnPc.

P3HT:PCBM with SiPc solar cells have also been studied recently [33-36], and the interface engineering for the ternary blend polymer solar cells were investigated and discussed in detail. In the present work, combination of the ternary blend polymers and DIO is an important point, and the microstructure model at the interface was proposed from XRD analysis and optical property measurements. Further optimization of the devices is mandatory to get higher performance in the future work.

\section{Conclusions}

PCBM: P3HT(ZnPc) bulk heterojunction solar cells with an inverted structure were fabricated and characterized. The 
short-circuit current density of the solar cells were improved by the $\mathrm{ZnPc}$ addition. IPCE spectra of the PCBM:P3HT(ZnPc) solar cells showed peaks at $690 \mathrm{~nm}$, and the IPCE intensities in the range of 400-650 nm were increased by the $\mathrm{ZnPc}$ addition. The absorption of the $\mathrm{ZnPc}$ was in the range of 550-800 $\mathrm{nm}$, and the photoluminescence of P3HT was in the range of $600-800$ $\mathrm{nm}$. Since the absorption range of $\mathrm{ZnPc}$ overlapped with the photoluminescence range of P3HT, the Förster energy transfer from $\mathrm{P} 3 \mathrm{HT}$ to $\mathrm{ZnPc}$ would occur. The increase in conversion efficiency of the PCBM: P3HT cells by the $\mathrm{ZnPc}$ addition would be explained in terms of the direct charge transfer from $\mathrm{ZnPc}$ to $\mathrm{PCBM}$ and the Förster energy transfer from $\mathrm{P} 3 \mathrm{HT}$ to $\mathrm{ZnPc}$. The Current density and efficiencies of PCBM:P3HT bulk heterojunction solar cells were also improved by the DIO addition, which would be due to the crystallite growth of the P3HT and phase separation of PCBM:P3HT layers.

\section{Acknowledgements}

This work was partly supported by Satellite Cluster Program of the Japan Science and Technology Agency, and a Grant-in-Aid for Scientific Research.

\section{REFERENCES}

[1] N. S. Sariciftci, L. Smilowitz, A. J. Heeger, F. Wudl, Photoinduced electron transfer from a conducting polymer to buckminsterfullerene, Science, Vol. 258, 1474-1496, 1992.

[2] M. Granström, K. Petritsch, A. C. Arias, A. Lux, M. R. Andersson, R. H. Friend, Laminated fabrication of polymeric photovoltaic diodes, Nature, Vol. 395, 260-257, 1998.

[3] T. Oku, A. Takeda, A. Nagata, H. Kidowaki, K. Kumada, K. Fujimoto, A. Suzuki, T. Akiyama, Y. Yamasaki, E. Ōsawa, Microstructures and photovoltaic properties of $\mathrm{C}_{60}$-based solar cells with copper oxides, $\mathrm{CuInS}_{2}$, phthalocyanines, porphyrin, PVK, nanodiamond, germanium and exciton-diffusion blocking layers, Materials Technology, Vol. 28, 21-39, 2013.

[4] P. Peumans, S. Uchida, S. R. Forrest, Efficient bulk heterojunction photovoltaic cells using small-molecular-weight organic thin films, Nature, Vol. 425, 158-162, 2003.

[5] M. Reyes-Reyes, K. Kim, D. L. Carroll, High-efficiency photovoltaic devices based on annealed poly (3-hexylthiophene)and 1-(3-methoxycarbonyl)-propyl-1phenyl- $(6,6) \mathrm{C}_{61}$ blends, Applied Physics Letters, Vol. 87, 083506-1-3, 2005.

[6] F. Padinger, R. S. Rittberger, N. S. Saruciftci, Effect of Postproduction Treatment on Plastic Solar Cells, Advanced Function Materials, Vol. 13, 85-88, 2003.

[7] J. A. Hauch, P. Schilinsky, S. A. Choulis, R. Childers, M. Biele, C. J. Brabec, Flexible organic P3HT:PCBM bulk-heterojunction modules with more than 1 year outdoor lifetime, Solar Energy Materials and Solar Cells, Vol. 92, 727-731, 2008

[8] Y. C. Huang, Y. C. Liao, S. S. Li, M. C. Wu, C. W. Chen, W. F. Su, Study of the effect of annealing process on the performance of $\mathrm{P} 3 \mathrm{HT} / \mathrm{PCBM}$ photovoltaic devices using scanning-probe microscopy, Solar Energy Materials and Solar Cells, Vol. 93, 888-892, 2009.

[9] W. H. Baek, H. Yang, T. S. Yoon, C. J. Kang, H. H. Lee, Y. S. Kim, Effect of P3HT:PCBM concentration in solvent on performances of organic solar cells, Solar Energy Materials and Solar Cells, Vol. 93, 1263-1267, 2009.

[10] G. Li, V. Shrotriya, Y. Yao, Y. Yang, Investigation of annealing effects and film thickness dependence of polymer solar cells based on poly(3-hexylthiophene), Journal of Applied Physics, Vol. 98, 043704-1-5, 2005.

[11] S. Honda, S. Yokoya, H. Ohkita, H. Benten, S. Ito, Light-Harvesting Mechanism in Polymer/Fullerene/Dye Ternary Blends Studied by Transient Absorption Spectroscopy, Journal of Physical Chemistry C, Vol. 115, 11306-11317, 2011.

[12] S. Honda, H. Ohkita, H. Benten, S. Ito, Selective Dye Loading at the Heterojunction in Polymer/Fullerene Solar Cells, Advanced Energy Materials, Vol. 1, 588-598, 2011.

[13] S. Honda, H. Ohkita, H. Benten, S. Ito, Multi-colored dye sensitization of polymer/fullerene bulk heterojunction solar cells, Chemical Communications, Vol. 46, 6596-6598, 2010.

[14] T. Oku, S. Nose, K. Yoshida, A. Suzuki, T. Akiyama, Y. Yamasaki, Fabrication and characterization of silicon naphthalocyanine, gallium phthalocyanine and fullerene-based organic solar cells with inverted structures, Journal of Physics: Conference Series, Vol. 433, 012025-1-7, 2013.

[15] T. Oku, S. Hori, A. Suzuki, T. Akiyama, Y. Yamasaki, Fabrication and characterization of PCBM:P3HT:silicon phthalocyanine bulk heterojunction solar cells with inverted structures, Japanese Journal of Applied Physics, Vol. 53, 05FJ08-1-5, 2014.

[16] K. Yoshida, T. Oku, A. Suzuki, T. Akiyama, Y. Yamasaki, Fabrication and characterization of PCBM:P3HT bulk heterojunction solar cells doped with germanium phthalocyanine or germanium naphthalocyanine, Material Sciences and Applications, Vol. 4, 1-5, 2013.

[17] T. Oku, K. Yoshida, A. Suzuki, T. Akiyama, Y. Yamasaki, Fabrication and characterization of PCBM:P3HT bulk heterojunction solar cells doped with silicon naphthalocyanine, Physica Status Solidi C, Vol. 10, 1836-1839, 2013.

[18] P. Peumans, S. R. Forrest, Very-high-efficiency double-heterostructure copper phthalocyanine $/ \mathrm{C}_{60}$ photovoltaic cells, Applied Physics Letters, Vol. 79, 126-128, 2001.

[19] L. Li, Q. Tang, H. Li, W. Hu, X. Yang, Z. Shuai, Y. Liu, D. Zhu, Organic thin-film transistors of phthalocyanines, Pure and Applied Chemistry, Vol.80, 2231-2240, 2008.

[20] N. M. Bamsey, A. P. Yuen, A.-M. Hor, R. Klenkler, J. S. Preston, R. O. Loutfy, Integration of a M-phthalocyanine layer into solution-processed organic photovoltaic cells for 
improved spectral coverage, Solar Energy Materials and Solar Cells, Vol. 95, 1970-1973, 2011.

[21] D. Y. Kim, F. So, Y. Gao, Aluminum phthalocyanine chloride $/ \mathrm{C}_{60}$ organic photovoltaic cells with high open-circuit voltages, Solar Energy Materials and Solar Cells, Vol. 93, 1688-1691, 2009.

[22] H. C. Liao, C. C. Ho, C. Y. Chang, M. H. Jao, S. B. Darling, W. F. Su, Additives for morphology control in high-efficiency organic solar cell, Materials Today, Vol. 16, 326-336, 2013

[23] X. Guo, C. Cui, M. Z. L. Huo, Y. Huang, J. Hou, Y. Li, High efficiency polymer solar cells based on poly(3-hexylthiophene)/indene- $\mathrm{C}_{70}$ bisadduct with solvent additive, Energy and Environmental Science, Vol. 5, 7943-7949, 2012

[24] F. C. Krebs, Air stable polymer photovoltaics based on a process free from vacuum steps and fullerenes, Solar Energy Matererials and Solar Cells, Vol. 92, 715-726, 2008.

[25] B. Walker, C. Kim, T.-Q. Nguyen, Small Molecule Solution-Processed Bulk Heterojunction Solar Cells, Chemistry of Materials, Vol. 23, 470-482, 2011.

[26] H. Y. Lin, W. C. Huang, Y. C. Chen, H. H. Chou, C. Y. Hsu, J. T. Lin, H. W. Lin, BODIPY dyes with $\beta$-conjugation and their applications for high-efficiency inverted small molecule solar cells, Chemical Communications, Vol. 48, 8913-8915, 2012.

[27] T. Kuwabara, T. Nakayama, K. Uozumi, T. Yamaguchi, K. Takahashi, Highly durable inverted-type organic solar cell using amorphous titanium oxide as electron collection electrode inserted between ITO and organic layer, Solar Energy Materials and Solar Cells, Vol. 92, 1476-1482, 2008.

[28] Y. Matsuo, J. Hatano, T. Kuwabara, K. Takahashi, Fullerene acceptor for improving open-circuit voltage in inverted organic photovoltaic devices without accompanying decrease in short-circuit current density, Applied Physics Letters, Vol. $100,063303,2012$
[29] A. Takeda, T. Oku, A. Suzuki, T. Akiyama, Y. Yamasaki, Fabrication and characterization of fullerene-based solar cells containing phthalocyanine and naphthalocyanine dimers, Synthetic Metals, Vol. 177, 48-51, 2013.

[30] T. Yamamoto, J. Hatano, T. Nakagawa, S. Yamaguchi, Y. Matsuo, Small molecule solution-processed bulk heterojunction solar cells with inverted structure using porphyrin donor, Applied Physics Letters, Vol. 102, 013305, 2013.

[31] S. R. Scully, P. B. Armstrong, C. Edder, J. M. J. Fréchet, M. D. McGehee, Long-range resonant energy transfer for enhanced exciton harvesting for organic solar cells, Advanced Materials, Vol. 19, 2961-2966, 2007.

[32] S. Honda, T. Nogami, H. Ohkita, H. Benten, S. Ito, Improvement of the light-harvesting efficiency in polymer/fullerene bulk heterojunction solar cells by interfacial dye modification, ACS Applied Materials and Interfaces, Vol. 1, 804-810, 2009.

[33] H. Xu, H. Ohkita, Y. Tamai, H. Benten, S. Ito, Interface engineering for ternary blend polymer solar cells with a heterostructured near-IR dye, Advanced Materials, Vol. 27, 5868-5874, 2015.

[34] L. Lu, M. A. Kelly, W. You, L. Yu, Status and prospects for ternary organic photovoltaics, Nature Photonics, 9, 491-500, 2015.

[35] H. M. Feier, O. G. Reid, N. A. Pace, J. Park, J. J. Bergkamp, A. Sellinger, D. Gust, G. Rumbles, Local intermolecular order controls photoinduced charge separation at donor/acceptor interfaces in organic semiconductors, Advanced Energy Materials, Vol. 6, 1502176-1-9, 2016.

[36] L. Ke, J. Min, M. Adam, N. Gasparini, Y. Hou, J. D. Perea, W. Chen, H. Zhang, S. Fladischer, A. -C. Sale, E. Spiecker, R. R. Tykwinski, C. J. Brabec, T. Ameri, A Series of pyrene-substituted silicon phthalocyanines as near-IR sensitizers in organic ternary solar cells, Advanced Energy Materials Vol. 6, 1502355-1-13, 2016. 